\title{
Studies on sensory characteristics of ginger (Zingiber officinale L.) milk shake
}

\author{
SONALI JADHAV, R. M. KADAM, V. N. PATIL, P. S. NAIK AND S.V. JOSHI
}

\begin{abstract}
India is the largest milk producing country in the world with 114.4 million tones milk production and per capital availability 268g/day (Kalalselvi and Somasundaram, 2011). Milk shake, a product of Western origin, is obtained by freezing a mix very similar to soft serve ice-cream mix and speed mixing the frozen product in a mixture to make it pourable and generate foam in it. It has lower fat and sugar contents and higher milk SNF content than ice-cream. Ginger is a popular home remedy in India today. The medicinal properties of ginger in preventing cough and cold are well documented taking into account the medicinal properties of ginger, the present research on studies on sensory characteristics ginger (Zingiber officinale L.) milk shake by addition of ginger juice control, 2.5 per cent, 5 per cent, 7.5 per cent, 10 per cent of milk (V/V). Different sensory characteristics are done i.e. general apperance, flavaur, concestancy and overall aceptability. Most aceepted treatment found i.e. ginger juice 5 per cent of of $\operatorname{milk}(\mathrm{v} / \mathrm{v})$.
\end{abstract}

KEY WORDS : Buffalo milk, Ginger, Extraction of ginger juice, Sensory characteristics, Milk shake

How TO CITE THIS PAPER : Jadhav, Sonali, Kadam, R.M., Patil, V.N., Naik, P.S. and Joshi, S.V. (2017). Studies on sensory characteristics of ginger (Zingiber officinale L.) milk shake. Res. J. Animal Hus. \& Dairy Sci., 8(2) : 103-107 : DOI: 10.15740/HAS/RJAHDS/8.2/103-107.

Address for correspondence :

Sonali jadhav, Department of Animal Husbandry and Dairy Science, Rajmata Jijau Girls Hostel, College of Agriculture, Vasantrao Naik Marathwada Agriculture University, PARBHANI (M.S.) INDIA

Email : sonali_2095@rediffmail.com

Associated Authors' :

R.M. Kadam and S.V. Joshi, Department of Animal Husbandry and Dairy Science, College of Agriculture, Dr. Balasaheb Sawant Konkan Krishi Vidyapeeth, Dapoli, RATNAGIRI (M.S.) INDIA

V. N. Patil, Agriculture Technology School Killa-Roha, RAIGAD (M.S.) INDIA P.S. Naik, Poonam Naik At Post Akeri Bhagevadi, SINDHUDURG (M.S.) INDIA 